\title{
The Effect Of Dividend, Board Characteristics, Information Asymmetry Towards Cash Holding On Manufacturing Company
}

\author{
Nurainun Bangun ${ }^{1}$, Yuniarwati ${ }^{2}$, Sani Setyawati Nyata Saputra ${ }^{3}$ \\ \{Inun66@yahoo.com ${ }^{1}$,yuniarwati@fe.untar.ac.id ${ }^{2}$, Elbersani@gmail.com $\left.{ }^{3}\right\}$ \\ ${ }^{1,2,3}$ Univeristas Tarumanagara, Jakarta, Indonesia
}

\begin{abstract}
The purpose of this research is to analyze the dividend payment, board characteristics and information asymmetry to cash holding. The sample of this study was selected using purposive sampling that amounted 48 company in Indonesian Stock Exchange within the year 2015-2017. Data processing techniques using multiple regression analysis that helped by SPPSS program for windows the $24^{\text {th }}$ version and Microsoft Excel 2013. The results of this study indicate that dividend payment have a positive significant influence to cash holding, board characteristics (board size and independence) does not have an influence to cash holding and information asymmetryhave a positive non-significant influence to cash holding.
\end{abstract}

Keywords: cash holding, dividend payment, board characteristics, information asymmetry

\section{Introduction}

Nowadays company's competition is now very tight, accompanied by a rapid economic development. Every company is expected to have the right strategy to survive in the market. One of the right strategies for survival is to attract the attention of investors, and certainly pay attention to the performance of the company which will be in the public and internal company spotlight, but not only that the company is also demanded for transparency and openness to the information provided.

The company's ability to fulfill its short-term obligations is usually called liquidity. As the most liquid assets, cash can be used for many things such as paying off short-term debt and meeting the operational needs of the company. Cash consists of currency (coins, paper), demand deposits (demand deposits, checks), and quasi money / deposits [1]. There are also currencies [2][2].

The inhibition of company operations can be due to lack of cash, one of the factors. The company has responsibility in managing existing cash, and what decisions or actions should be taken in managing it.

The existence of cash in the company must get the attention of the manager. Of course managers have many tasks and one of them is watching. Supervise the existence of cashrelated transactions within the company. Cash held or held in a company is commonly referred to as a cash holding. Having a large amount of cash is profitable, but if there is a positive there is a negative. As hampered the achievement of profit or optimal profit. Companies can be avoided from lack of funds and can finance unexpected needs. According to [3] if the company has large amounts of cash it will not damage the company's 
performance. If the company keeps too little cash, the company will have difficulty paying off its short-term obligations, and will have fewer opportunities to invest.

\section{Literatur Riview}

\subsection{Agency Theory.}

This theory is based on the relationship between shareholders / owners (principals) and management (agents). According to this theory, the relationship between the principal and the agent is usually difficult to create due to conflicts of interest [4]. [5] states that agency theory has a view of cash holding, namely: Free Cash Flow Hypothesis where cash holding can be seen as free cash flow because cash can be used to fulfill management interests and reduce shareholder interests and risk Hypothesis Reduction where cash holding is considered to be a risk-free investment according to the risk reduction hypothesis and by increasing cash holding is a way of management to avoid risk. According to Chireka \& Fakoya, agency theory has its own views on cash holding, namely:

\subsubsection{Free Cash Flow Hypothesis}

Cash holding can be seen as free cash flow because cash can be used to fulfill management interests and reduce the interests of shareholders. Increased assets in companies because managers hold cash, and that makes managers able to make decisions for companies and invest [5].

\subsubsection{Risk Reduction Hypothesis}

Management conflicts occur because of the different risk-taking patterns between shareholders and management. According to Tong [5] cash holding is considered to be a riskfree investment according to the risk reduction hypothesis and by increasing cash holding is a way of management to avoid risk.

\subsection{Pecking Order Theory}

According to Myers \& Majluf [5] this theory is an illustration of the degree to which companies are seeking funding. The company prefers to use internal equity in investing and using it in the company's growth [5].[5] states that the pecking order theory assumes that the cash level is not optimal. However, cash can act as a buffer beam between retained earnings and investment needs. High cash, the company certainly believes that the profitability of its investment and excess cash will be distributedconst to shareholders (cash dividend). Corporate financing comes from financing hierarchies where financing is divided into three sources, the highest being internal financing, after which debt issuance and finally equity issuance.

\subsection{The trade-off theory}

According to the Trade-off Theory, companies make the optimal cash holding to maximize shareholder welfare [6]. This theory is also supported by the motives of holding cash from Keynes (1963), namely the motives of transactions, the motives of guarding and motives of speculation. In the motive for transacting the company can avoid transaction costs that use cash or liquidate assets. The motive for transacting from Keynesian theory also 
benefits companies to save cash to overcome opportunity costs [6]. Motives stand guard to prove that the cash holding can help companies invest or finance projects. According to Tobin, 1956, Miller 1966, Dittmar 2003 [6] the motive for transacting from Keynesian theory also benefits companies to save cash to overcome opportunity costs.

Motives stand guard to prove that the cash holding can help companies invest or finance projects. Ozkan ([6] emphasizes that to overcome the possibility of higher external costs, companies can invest in liquid assets or increase their cash. There are three benefits in holding cash, companies can avoid financial distress, companies can invest when financial difficulties, and can reduce asset conversion costs. [6] has shortcomings, which can increase agency cost. Companies that have high cash holding rates can allow no access to the capital market. Therefore, managers will be more concerned with their own interests than shareholders [6].

Cash holding according to PSAK No. 2

"Cash consists of cash balance (cash on hand) and account giro (deposit). Cash equivalents (cash equivalents) are investments that are highly liquid, short-term, which can quickly be converted into cash in a predetermined amount and risk the risk of insignificant changes in value "

According to [5], there are four motives for holding money, namely:

\section{The transaction motive}

This transaction motif is the most classic model to fulfill cash demand, this motif was popularized in the 1960 s by Miller and Orr (1996). Companies that have low or little cash levels will have difficulty in financing other obligations or funding and companies must sell non-cash assets to meet those needs.[5].

\section{The precautionary motive}

Companies will tend to hold higher cash to anticipate future unstable cash demand (Bates et al, 2009). According to Almeida, Campello and Weishbach (2004) companies that experience financial difficulties will tend to use the precautionary motive. Companies that anticipate future financial difficulties in terms of investment and fulfillment of operations will tend to rely on cash holding.

\section{The tax motive}

Tax returns can affect cash holding in companies in the United States, according to research from Foley, Hartzell, Titman, and Twite in 2007[5]. The United States imposes a tax on income derived from foreign operations of local businesses, even though they provide tax credits for foreign taxes paid on foreign operations. found that companies that were exposed to a greater tax burden on repatriated profits would have more cash.

\section{The speculative motive}

Speculating motives have the purpose of gaining profits on a profitable investment opportunity. Research by Kariuki, Namusonge and Orwa, 2015 provides evidence that the existence of a cash holding is to increase this speculation activity. The purpose of all businesses is to make a profit, and allocate these profits by sharing with shareholders, paying off debts, etc.

Cash is owned by the company aimed at fulfilling short-term obligations, and not for investment or other purposes. In meeting qualifications as cash equivalents, investments must 
be converted into cash and the risk of change in value is not significant. An ordinary investment qualifies as cash when it is near due date[7]. Cash consists of coins, paper, demand deposits, checks, and quasi / deposit money [1] , and there are also currencies [2]. Having enough cash in the company will help in the running of operations, but when too much cash is available the company will lose the opportunity to invest. Fulfilling future cash demand and financing unexpected costs is also a benefit of having a high level of cash.

Board independence is an independent board of commissioners who do not have corporate management, share ownership or the influence of family relations with other board members. Independent commissioners have a responsibility to help improve transparency and transparency of information [8] .Research conducted by [9] shows board independence results have a negative relationship and a significant effect on cash holding. Research conducted by [10] shows that board independence has no influence on cash holding.

Board Size is part of the company. The board of commissioners has a role in the company, namely overseeing the company's performance and decisions taken by the board of directors [10]. According to [9] the board size has a significant negative relationship to the cash holding, but the research was conducted on companies in China. However, according to the research results of [11] the board size has an insignificant influence and a negative relationship to the cash holding.

Information asymmetry is where one party has more or better information than the other party, or information asymmetry can also be said as information discontinuation [12]. According to the results of research from Information asymmetry has no effect on cash holding. According to research conducted by [3] information asymmetry has an influence and has a negative relationship to cash holding and according to the results of research conducted by [13] information asymmetry has no effect on cash holding.

Dividends are distributions or distributions in the form of cash or shares or other forms by the company to shareholders using a percentage of ownership. According to research by Trust and [5] dividend payments have a positive relationship to cash holdings). According to [14], dividend payments have no influence on cash holding. Dividends in the form of profit sharing are one of the expectations desired by shareholders. Dividends can be distributed in various forms, cash dividends, dividend or property shares [2]. According to the trade-off theory, the relationship between dividend payment and cash holding is negative. According to [15] the dividend payment has a negative influence on the cash holding, according to [14] the dividend payment has no effect on the cash holding and according to the Trust and Fakoya (2017) the dividend payment has a positive influence on the cash holding.

The framework of thought in this study is the following picture below: 


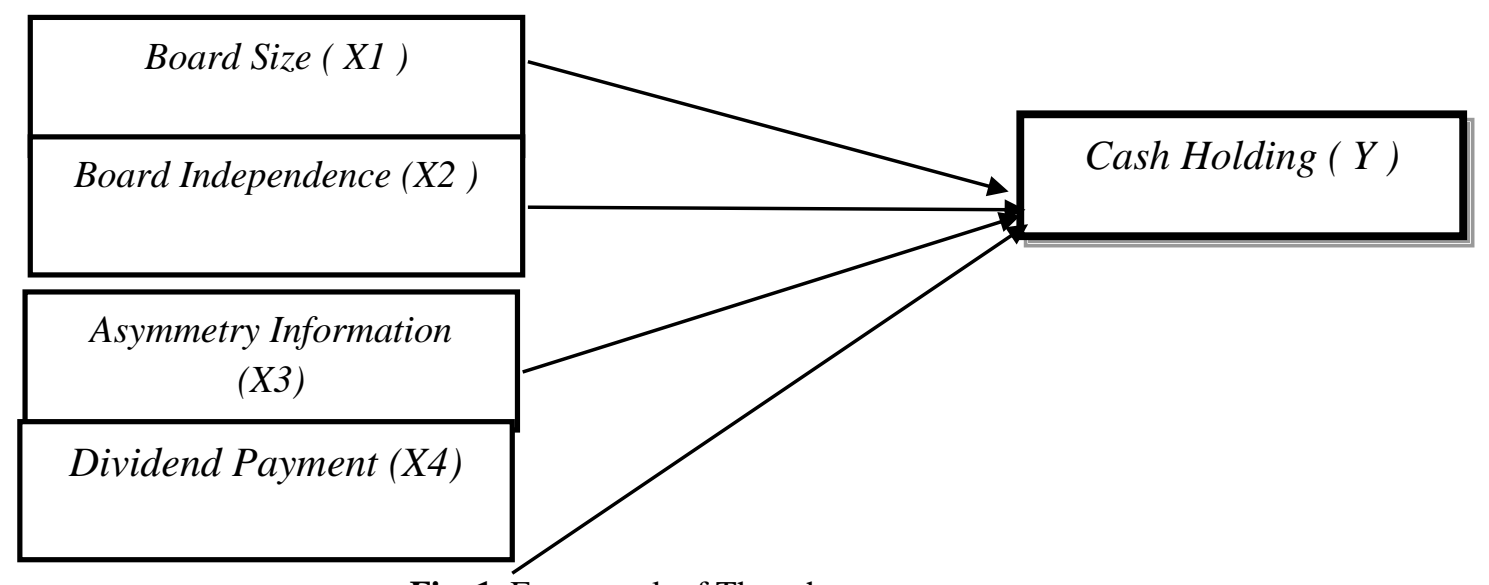

Fig. 1. Framework of Thoughts

The hypotheses of the above models are as follows:

H1 : Board Size has influence on cash holding

$\mathrm{H} 2$ : Board Independence has influence on cash holding

H3 : Information Asymmetry has negative influence on cash holding

$\mathrm{H} 4$ : Dividend Payment has negative influence on cash holding

\section{Methodology}

The object of research in this study is dividend payment, board size, board independence and information asymmetry, which is focused on manufacturing companies listed on the Indonesia Stock Exchange for the 2015-2017 period where financial data or reports are obtained from the IDX website, www.idx.co.id. The sample selection is done by purposive sampling method with the following criteria: a) Manufacturing companies listed on the Indonesia Stock Exchange during the period 2015-2017. b) Manufacturing companies that present financial statements in Rupiah in the 2015-2017 period. c) Manufacturing companies that record profits during the 2015-2017 period are kneeling. d) Manufacturing companies that present complete financial reports with variables related to research in the 2015-2017 period. e) Companies that have an independent board of commissioners and board of commissioners during 2015-2017. f) Companies that provide stock price data in the 2015-2017 period. g) Manufacturing companies that do not carry out delisting / relisting during 2015-2017. The amount of data that meets the requirements is 48 companies.

The operational variables in this study consisted of cash holding, dividend payment, board size, board independence and information asymmetry, where cash holding as an independent variable in this study has a formula:

$$
\text { Cash Holding }(\mathrm{CASH})=\frac{\text { Cash and Cash equivalent }}{\text { Total Assets }}
$$

The Payment dividend in this study was measured using Dummy. Where companies that distribute dividends are given a number (1) and companies that do not distribute dividends are given a zero $(0)$.

The Board Size in this study is measured by summing the total board of commissioners owned by the company, which produces the following formula: 
Board Size $(\mathrm{Bs})=\sum$ total board of commissioners in the company

Board Independence in this study is measured by summing the total independent commissioners inside the company, the formula as follows:

Board Independence $($ Bind $)=\sum$ total independent commissioner

Information Asymmetry in this study is represented by the SPREAD formula

$$
\text { Information Asymmetry (IA) }=\frac{A s k-B i d}{(A s k+B i d) / 2} \times 100
$$

Ask Price : The highest stock price in company $\mathrm{X}$ in year $\mathrm{i}$

Bid Price : The lowest stock price in company $\mathrm{X}$ in year $\mathrm{i}$

This research uses Descriptive Statistics Test in testing sample data, classic assumption test which consists of Normality Test, Multicollinearity Test, Heterocedasticity Test and Autocorrelation Test. Then to test the hypothesis this study will use the coefficient of determination test, correlation coefficient test, $\mathrm{t}$ test and $\mathrm{F}$ test.

Tabel 1. Summary of Variable Operationalization

\begin{tabular}{|c|c|c|}
\hline Variable & Standard & Scale \\
\hline Cash Holding (Y) & Cash Holding $(\mathrm{CH})=\frac{\text { Cash and Cashequivalent }}{\text { Total Assets }}$ & Ratio \\
\hline $\begin{array}{l}\text { Dividend Payment ( } \\
\mathrm{X} 1 \text { ) }\end{array}$ & Dummy, indicates the company that distributes dividends with 1 and those not with 0 . & Dummy \\
\hline Board Size (X2) & Board Size ( Bs) $=\sum$ total board of commissioners in the company & Nominal \\
\hline $\begin{array}{l}\text { Board Independence } \\
\text { (X3) }\end{array}$ & Board Independence ( Bind) $=\sum$ total independent commissioner & Nominal \\
\hline $\begin{array}{l}\text { Information } \\
\text { Asymmetry (X4) }\end{array}$ & Information Asymmetry ( IA ) $=\frac{A s k-B i d}{(A s k+B i d) / 2} \times 100$ & Ratio \\
\hline
\end{tabular}

Table 2. Descriptive Statistics Test Results

Descriptive Statistics

\begin{tabular}{|l|l|l|l|l|l|}
\hline & $\mathrm{N}$ & Minimum & Maximum & Mean & Std. Deviation \\
\hline $\mathrm{CH}$ & 144 &, 00190 &, 22910 &, 0738424 &, 05821083 \\
$\mathrm{DP}$ & 144 & 0 & 1 &, 73 &, 446 \\
$\mathrm{BS}$ & 144 & 1 & 8 & 2,71 & 1,404 \\
$\mathrm{BI}$ & 144 & 0 & 6 & 1,78 &, 964 \\
$\mathrm{AI}$ & 144 &, 00000 &, 46920 &, 1493515 &, 09762685 \\
Valid N (listwise) & 144 & & & & \\
\hline
\end{tabular}

Source : SPSS 24 processed results

Descriptive statistical tests will provide an overview of the data from the mean (mean), standard deviation, maximum and minimum so as to provide a description of the characteristics for this study sample[16]. Cash holding has an average of 0.0738424. This average value provides information that the average amount of cash held by manufacturing companies sampled in this study is $7.38 \%$ of the total assets of the company. The maximum value of CASH is 0.22910 . The minimum value is 0.00190 . The standard deviation value of 
the $\mathrm{Y}$ variable in this study is 0.05821 which indicates a value lower than the average value. These results indicate that the value of the variable is too gathered (has the same value). Dividend payment has an average value of 0.73 while the standard deviation value is 0.446 . The total companies that distribute dividends are 105 out of 144 samples, while those that do not distribute dividends are 39 out of 144 samples. Board Size (Bs) has 144 samples, the highest or maximum value of $\mathrm{Bs}$ is 8 . The lowest or minimum value of $\mathrm{Bs}$ is 1 . The average value of $\mathrm{Bs}$ is 2.72 while the standard deviation value is 1.420 which means it has a lower value than average value. Board Independence (Bind) has the highest value of 6 . The lowest value of board independence is 1 . Information asymmetry or information asymmetry symbolized by IA. The average value of IA with N 144 is 0.149352 and has a standard deviation of 0.097627 which is smaller than the average value, this can cause an average value that collects from a variable. The maximum value of information asymmetry is $46.92 \%$ or 0.46920 , while the minimum value of information asymmetry is 0.00000 .

The first variable (X1) of this research is dividend payment, in this study dividend payment will be calculated using a dummy, therefore companies that distribute dividends will be given the number 1 and the non-dividing ones will be given the number 0 . The sample used is 144 , the average value from the dividend payment is 0.73 while the standard deviation value is 0.446 . The total companies that distribute dividends are 105 out of 144 samples, while those that do not distribute dividends are 39 out of 144 samples. The second independent variable (X2) in this study is the board size symbolized by Bs which is calculated by summing the total board of commissioners in one company. The third independent variable (X3) is board independence symbolized by Bind. The calculation from Bind is the same as the Bs calculation, which is by adding up the independent board of commissioners in the company.

Table 3. One-Sample Kolmogorov-Smirnov Test

\begin{tabular}{|ll|l|}
\hline & & $\begin{array}{l}\text { Unstandardized } \\
\text { Residual }\end{array}$ \\
\hline N & Mean & 144 \\
Normal Parameters & & $0 \mathrm{E}-7$ \\
& Std. Deviation &, 05377007 \\
& Absolute &, 107 \\
Most Extreme Differences & Positive &, 107 \\
& Negative &,- 078 \\
Kolmogorov-Smirnov Z & & 1,285 \\
Asymp. Sig. (2-tailed) & &, 073 \\
\hline
\end{tabular}

a. Test distribution is Normal.

b. Calculated from data.

Source: results of normality test with SPSS 24 
Before testing the hypothesis, a classic assumption test will be carried out. The normality test has the purpose of knowing whether in a regression model, the error has a normal distribution or not. The assumption of multivariative normality is an assumption regarding each variable and from a linear combination of variables that have a normal distribution [16]. This study uses Kolmogorov-Smirnov analysis, the results of the study show 0.073 which is greater than 0.05 and means that the independent variable has been normally distributed.

Table 4. Multicollinearity Test Results

\begin{tabular}{|c|c|c|c|c|c|c|c|}
\hline \multirow[t]{2}{*}{ Model } & \multicolumn{2}{|c|}{\begin{tabular}{|l|} 
Unstandardized \\
Coefficients \\
\end{tabular}} & \begin{tabular}{|l|} 
Standardized \\
Coefficients \\
\end{tabular} & \multirow[t]{2}{*}{$\mathrm{t}$} & \multirow[t]{2}{*}{ Sig. } & \multicolumn{2}{|c|}{$\begin{array}{l}\text { Collinearity } \\
\text { Statistics }\end{array}$} \\
\hline & $\mathrm{B}$ & Std. Error & Beta & & & Tolerance & VIF \\
\hline (Constant) & 011 & ,014 & & ,733 & ,465 & & \\
\hline DP & ,033 & ,010 &, 251 & 3,174 & ,002 & ,978 & 1,023 \\
\hline $1 \mathrm{BS}$ & ,004 & ,004 &, 107 & 1,094 &, 276 & ,646 & 1,548 \\
\hline BI &, 010 & ,006 &, 160 & 1,635 & ,104 & ,644 & 1,552 \\
\hline AI &, 068 & 047 &, 114 & 1,458 & 147 & ,996 & 1,004 \\
\hline
\end{tabular}

a. Dependent Variable: $\mathrm{CH}$

This multicollinearity test was conducted to see whether in the research regression model there was a correlation between independent variables (free). This study uses the basis of VIF and tolerance values. VIF value for dividend payment is 1.023 , VIF value for board size is 1.548, VIF value for board independence is 1.552 and VIF value for information asymmetry is 1.004. All VIF values for the four independent variables have a value of less or below 10 . Therefore, it can be concluded that the regression model of this study does not have multicollinearity.

Table 5. Autocorrelation Test Results

\begin{tabular}{|c|c|c|c|c|c|}
\hline \multicolumn{6}{|c|}{ Model Summary ${ }^{b}$} \\
\hline Model & $\mathrm{R}$ & R Square & Adjusted R Square & $\begin{array}{l}\text { Std. Error of the } \\
\text { Estimate }\end{array}$ & $\begin{array}{l}\text { Durbin- } \\
\text { Watson } \\
\end{array}$ \\
\hline 1 &, $383^{a}$ &, 147 &, 122 &, 05453825 & 1,828 \\
\hline
\end{tabular}

Autocorrelation test to test the linear regression model of the relationship (correlation) between the error or confounding error in period $t$ with the interfering error in the previous period. This study uses the Durbin Watson test where the result of the Durbin-Watson (Dw) value is 1,828 , du for 144 samples is 1,785 , the constant $(\mathrm{k})$ in this test is 4 , thus it can be written $4-\mathrm{du}=4-1,7851=2,2149$. The equation obtained is $\mathrm{du}<\mathrm{Dw}<4-\mathrm{du}, 1,7851$ $<1,828<2,2149$. So, the linear regression model of this study has no autocorrelation problem. 
Table 6. Heteroscedasticity Test Results

Coefficients $^{\mathrm{a}}$

\begin{tabular}{|l|l|l|l|l|l|}
\hline \multirow{2}{*}{ Model } & \multicolumn{2}{|l|}{ Unstandardized Coefficients } & $\begin{array}{l}\text { Standardized } \\
\text { Coefficients }\end{array}$ & t & Sig. \\
\cline { 2 - 5 } & B & Std. Error & Beta & & \\
\hline (Constant) &, 034 &, 008 & & 4,150 &, 000 \\
DP &, 011 &, 006 &,- 163 & 1,947 &, 053 \\
\hline BS &,- 003 &, 002 &, 132 & $-1,522$ &, 130 \\
\hline BI &, 004 &, 003 &, 077 & 1,285 &, 201 \\
AI &, 024 &, 026 &, 930 &, 354 \\
\hline
\end{tabular}

a. Dependent Variable: ABSRES

The Heteroscedasticity test has the purpose of testing the research regression model whether it contains variance inequalities from one value to another. This study uses the Glejser test, the results of the study show that the significance value of the independent dividend payment variable is $0.053(5.3 \%)$, board size $0.130(13 \%)$, board independence $0.201(20.1 \%)$ and significance value for the independent variable information asymmetry is $0.354(35.4 \%)$. The significance value for each independent variable exceeds $0.05(5 \%)$ and it can be concluded that the regression model in this study has no problem with heteroscedasticity. Based on the results of the research that has been carried out, the researcher gives the findings of the findings, namely the results of the test of multiple regression analysis

Table 7. Test Results for Multiple Regression Analysis

\section{Coefficients $^{\mathrm{a}}$}

\begin{tabular}{|c|c|c|c|c|c|c|c|}
\hline \multirow[t]{2}{*}{ Model } & \multicolumn{2}{|c|}{$\begin{array}{l}\text { Unstandardized } \\
\text { Coefficients }\end{array}$} & \multirow{2}{*}{\begin{tabular}{|l|}
$\begin{array}{l}\text { Standardized } \\
\text { Coefficients }\end{array}$ \\
Beta \\
\end{tabular}} & \multirow[t]{2}{*}{$t$} & \multirow[t]{2}{*}{ Sig. } & \multicolumn{2}{|c|}{$\begin{array}{l}\text { Collinearity } \\
\text { Statistics }\end{array}$} \\
\hline & B & Std. Error & & & & Tolerance & VIF \\
\hline (Constant) &, 011 &, 014 & &, 733 & ,465 & & \\
\hline DP & ,033 &, 010 &, 251 & 3,174 &, 002 & ,978 & 1,023 \\
\hline $1 \mathrm{BS}$ &, 004 & ,004 &, 107 & 1,094 & ,276 & ,646 & 1,548 \\
\hline BI &, 010 & ,006 &, 160 & 1,635 &, 104 & ,644 & 1,552 \\
\hline AI & ,068 & ,047 &, 114 & 1,458 &, 147 & ,996 & 1,004 \\
\hline
\end{tabular}

a. Dependent Variable: $\mathrm{CH}$

Source: Results of Data Processing with SPSS 24 


$$
\mathrm{Y}=0,011+0,033 \times 1+0,004 \times 2+0,010 \times 3+0,068 \times 4+e
$$

From the above equation shows a constant coefficient of 0.011 , which means the value of the dependent variable $(\mathrm{Y})$ will be 0.011 units if independent variables $(\mathrm{X})$ board size, board independence, dividend payment, and information asymmetry are given zero. That is, there are still independent variables that can affect the dependent variable in this study. The dividend payment value is 0.033 , which means that every increase in one dividend payment unit will make an increase in the cash holding of 0.033 units but with the condition of the other independent variables constant. The board size value is 0.004 which means that any increase in one board size unit will increase the cash holding by 0.004 units where the other independent variables are constant. Board independence value is 0.010 in table 4.8 means that each increase in one board independence unit will increase the cash holding by 0.010 units where the other independent variables are constant. The value of information asymmetry is 0.068 means that each increase in one unit of information asymmetry will increase the cash holding by 0.068 units, where the other independent variables are constant.

$\mathrm{T}$ test (partial test) will see the effect of the independent variables respectively on the dependent variable. The independent variable will be said to have an influence on the dependent variable when having a p value (sig) smaller than the level of significance.[16].

Table 8. Partial Test Results (T Test)

\section{Coefficients $^{a}$}

\begin{tabular}{|c|c|c|c|c|c|}
\hline \multirow[t]{2}{*}{ Model } & \multicolumn{2}{|c|}{$\begin{array}{l}\text { Unstandardized } \\
\text { Coefficients }\end{array}$} & \multirow{2}{*}{$\begin{array}{l}\text { Standardized } \\
\text { Coefficients } \\
\text { Beta }\end{array}$} & \multirow[t]{2}{*}{$t$} & \multirow[t]{2}{*}{ Sig. } \\
\hline & B & Std. Error & & & \\
\hline (Constant) & ,011 & ,014 & &, 733 &, 465 \\
\hline DP & ,033 &, 010 &, 251 & 3,174 &, 002 \\
\hline $\mathrm{BS}$ & ,004 & ,004 &, 107 & 1,094 & ,276 \\
\hline BI & ,010 & ,006 &, 160 & 1,635 &, 104 \\
\hline AI & ,068 &, 047 &, 114 & 1,458 &, 147 \\
\hline
\end{tabular}


a. Dependent Variable: $\mathrm{CH}$

Source: Results of Data Processing with SPSS 24

Table 9. Determination Coefficient Test Result $\left(\mathrm{R}^{2}\right)$

\begin{tabular}{|l|l|l|l|l|}
\hline Model & R & R Square & Adjusted R Square & $\begin{array}{l}\text { Std. Error of the } \\
\text { Estimate }\end{array}$ \\
\hline 1 &, $383^{\text {a }}$ &, 147 &, 122 &, 05453825 \\
\hline $\begin{array}{l}\text { a. Predictors: (Constant), AI, DP, BS, BI } \\
\text { b. Dependent Variable: CH }\end{array}$
\end{tabular}

test which tests the effect of the dependent variable on the independent variables of the study. The $\mathrm{R}^{2}$ test results show the Adjusted $\mathrm{R}$ Square value of 0.147 which means that the independent variable of this study which means dividend payment, board size, board independence, and information asymmetry can explain the dependent variable, which means a cash holding of $14.7 \%$. Test the correlation coefficient ( $\mathrm{R}$ test) which aims to measure the strength of the relationship between variables, in this study the $R$ test results show an $R$ value of 0.383 where $\mathrm{R}<0.5$, which means the independent variable has a weak influence on the dependent variable of the study.

\section{Discussion}

Statistical test results based on Partial Test (T Test) shows that Board Size has no effect on Cash Holding. This is because the commissioner does not have direct control of the cash holding company, which has more control, is the board of directors advised by the board of commissioners.

The $\mathrm{R}^{2}$ test results shown in table 4.9 show the Adjusted $\mathrm{R}$ Square value of 0.147 which means that the independent variable of this study which means dividend payment, board size, board independence, and information asymmetry can explain the dependent variable, which means a cash holding of $14.7 \%$ the remaining $85.3 \%$ is explained by the independent variables in this study. 
Seeing the value of $\mathrm{R}$ in table 4.10 in column $\mathrm{R} 0.383$, which means the value of $\mathrm{R}<0.5$, it can be stated that the independent variables of the research, namely dividend payment, board size, board characteristics and information asymmetry in this study have a weak influence on the dependent variable of research namely cash holding. Based on the results of the partial test ( $T$ test) the board size has a $\mathrm{p}$ value of 0.276 which means it is greater than 0.05 , therefore Ha is rejected and Ho is accepted. Board size has no effect on cash holding. The results of this study contradict the results of [9] study which showed a negative relationship to cash holding and the results of research by [10] which said the board size had a significantly positive relationship to cash holding. The results of the research that are in accordance with the results of this study are the studies conducted by [11].

The $\mathrm{F}$ test is used to see whether the independent variables simultaneously affect the dependent variable. Significance value (from table coefficient) seen from the value of $\alpha$ is 0.05 . If the significance value is $<0.05$, it can be concluded that the hypothesis test is accepted and there is an influence between the independent variables on the dependent variable. If the significance value is $>0.05$, the hypothesis test is rejected and it is concluded that there is no influence between the independent variables on the dependent variable [16].

Board independence does not have a significant effect on Cash Holding, the existence of an independent board of commissioners or board of commissioners in a company is not an indicator in determining the amount of cash held by the company. The board of commissioners will guarantee the welfare of shareholders by giving advice to directors, which means having indirect control over cash holding. Based on the results of the partial test (T test), board independence has a p value of 0.104 which means it is greater than 0.05 . Thus, Ha is rejected and Ho is accepted, so board independence has no influence on the cash holding. This result is contrary to the results of research by [9] which shows that board independence has a negative relationship and a significant effect on cash holding. The results of this study are in accordance with the results of a study conducted by [10] showing board independence has no influence on cash holding and research results from [11].

Information Asymmetry has a insignificant positive effect on Cash Holding, contrary to the research of [17] Who said this result is not in line with the signaling theory that the existence of information asymmetry will result in a decrease in investor confidence in the company that will make it difficult to collect and cash The holding will increase to finance the company's internal. However, the results of this study indicate the absence of the influence of information asymmetry on cash holding, which may be due to the fact that managers are concerned about shareholder welfare, which means increasing existing cash holding to be shared with shareholders. Based on the results of the partial test ( $\mathrm{T}$ test), information asymmetry has a $\mathrm{p}$ value of 0.147 which means greater than 0.05 , therefore $\mathrm{Ha}$ is accepted and Ho is rejected. Thus the conclusion that can be taken is that information asymmetry has a not significant positive effect on cash holding. The results of this study are contrary to the research conducted by [3] who showed that information asymmetry has an influence and has a negative relationship to cash holding, research conducted by[13] information asymmetry has no influence towards cash holding and research conducted by [17].

While the Dividend Payment variable has a significant positive effect on Cash Holding, the company distributes dividends with the aim of increasing shareholder welfare and returning investors, the company will tend to hold high cash to guarantee investors. Partial test results show dividend payment has $\mathrm{p}$ value 0.002 which means it is smaller than 0.05 , therefore, it can be concluded $\mathrm{Ha}$ is accepted and Ho is rejected. Dividend payment has a significant positive effect on cash holding. The results of this study contradict the trade-off theory which says there is a negative relationship between dividend payment and cash holding. According 
to the trade-off theory, companies will have a low cash holding rate for those who distribute dividends because companies tend to collect funds when needed by using fees for dividend distribution to replace cash.

These results are in accordance with the results of research conducted by the results of research by Trust and Fakoya (2017) which show a positive relationship between dividend payment and cash holding and in contrast to [15] which shows a negative influence on the holding cash from dividend payments and research results from [14] which say the dividend payment has no effect on cash holding.

\section{Conclusions}

Based on the test results in the research conducted at the manufacturing companies listed on the Stock Exchange in the period 2015-2017, the cash holding is not influenced by board size, board independence and information asymmetry, this may be because the board of commissioners in Indonesian companies have no duty to focus on cash holding in companies and companies tend not to have agency problems so that asymmetry information has no significant effect, but cash holding is significantly affected by dividend payment. This may be due to the distribution of cash dividends and the purpose of the cash holding itself, one of which is to share with investors.

According to the results of hypothesis testing that has been done for this study in knowing the effect of dividend payment on cash holding it can be concluded that the independent variable dividend payment (X1) has a significant positive effect on cash holding. Dividend payment is calculated by dummy which indicates that the company that distributes dividends with 1 and which does not distribute is given a mark of 0 . Companies that tend to have a goal to distribute dividends will tend to have or choose to save more cash. The results of this study contradict the trade-off theory which says there is a negative relationship between dividend payment and cash holding. According to the trade-off theory, companies will have a low cash holding rate for those who distribute dividends because companies tend to raise funds when needed by using fees for dividend distribution to replace cash.

Based on the results of hypothesis testing conducted by researchers, it can be concluded that the independent variable board size (X2) does not have a significant effect on cash holding. Board size is calculated by summing the total board of commissioners in the company. This is because the commissioner does not have direct control of the company's cash holding, which has more control, the board of directors is advised by the board of commissioners, therefore the existence of the board of commissioners cannot be an indicator in detained cash determinants.

Based on the results of the hypothesis test, it can be concluded that the independent board independence variable (X3) has no effect on the cash holding. Board independence is calculated in the same way as the board size, which is by summing all the independent commissioners owned by a company. The board of commissioners cannot be a determinant indicator of cash holding in the company, and does not have direct control of the cash held in the company where the board of commissioners has a role in advising the board of directors in making decisions, one of which is to distribute dividends. The limitations of this study are

1. This research shows less results, because the value of this research $R^{2}$ is $14.7 \%$, which means that the independent variable in this study, namely dividend payment, board size, board independence and information asymmetry can explain the dependent variable of this research is a holding cash of $14,7 \%$ and $85.3 \%$ are influenced by other variables. 
2. This study also has limitations in the selection of samples, because this study only uses a sample of manufacturing companies listed on the Indonesia Stock Exchange (IDX).

3. This study has limited time, because it only uses three periods in choosing a research sample. The period used in this study is the period 2015-2017.

4. This study only has four independent variables, namely dividend payment, board size, board independence and information asymmetry, while the dependent variable of this research is cash holding.

5. This study has only a few journals or references, because the relationship between the independent variables and the dependent variable is less related.

Then the researcher gave several suggestions to help further research, namely

1. Further research is expected to add to the research sample from many other sectors not only from the manufacturing sector. So that it can produce more accurate results.

2. Further research is expected to increase the period of research so that it is not limited to just three years. So the results can be more accurate and can reflect the actual situation.

3. Future studies are expected to have a higher coefficient of determination than this study by using variables that are more appropriate or related to the dependent variable.

4. The next research is expected to show more convincing results in the influence between independent variables and the dependent variable of the study.

5. Future studies are expected to be able to choose the related variables to test the cash holding in order to have more and more convincing references.

\section{Reference}

[1] Yanuar, Ekonomi Makro: Suatu Analisis Konteks Indonesia, 3rd ed. Jakarta: Yayasan Mpu Ajar Artha., 2016.

[2] J. J. Weygandt, P. D. Kimmel, and D. E. Keiso, Intermediate Accounting, : : IFRS 3rd., vol. 5, no. 1. Hoboken, ew Jersey: John Wiley \& Sons, 2018.

[3] K. H. Chung, J. C. Kim, Y. S. Kim, and H. Zhang, "Information Asymmetry and Corporate Cash Holdings," J. Bus. Financ. Account., vol. 42, no. 9-10, pp. 1341-1377, 2015.

[4] N. Fadjrih Asyik, "PERSPEKTIF AGENCY THEORY: PENGARUH INFORMASI ASIMETRI TERHADAP MANAJEMEN LABA (Menggunakan Pendekatan Agency Framework)," EKUITAS (Jurnal Ekon. dan Keuangan), vol. 4, no. 1, p. 29, 2016.

[5] T. Chireka and M. B. Fakoya, "The determinants of corporate cash holdings levels: Evidence from selected South African retail firms," Invest. Manag. Financ. Innov., vol. 14, no. 2, pp. 79-93, 2017.

[6] M. S. Tahir, M. N. Alifiah, M. U. Arshad, and F. Saleem, "Financial theories with a focus on corporate cash holding behavior: A comprehensive review," Int. J. Econ. Financ. Issues, vol. 6, no. 3, pp. 215-219, 2016.

[7] PSAK No.2, PSAK-2-Laporan-Arus-Kas-IAS-7-04022017. 2017.

[8] Mawardi and Nurhalis, "Pengaruh Corporate Governance Terhadap Cash Holding Pada Perusahaan Manufaktur Di Bursa Efek Indonesia Mawardi 1 , Nurhalis 2 1,2)," J. Manaj. dan Inov., vol. 9, no. 1, pp. 75-90, 2018.

[9] A. ur Rehman and M. Wang, "Corporate cash holdings and adjustment behaviour in chinese firms: An empirical analysis using generalized method of moments," 
Australas. Accounting, Bus. Financ. J., vol. 9, no. 4, pp. 20-37, 2015.

[10] S. Y. Senjaya and I. K. Yadnyana, "Analisis Pengaruh Investment Opportunity Set, Cash Conversion Cycle Dan Corporate Governance Structure Terhadap Cash Holdings," E-Jurnal Ekon. dan Bisnis Univ. Udayana, vol. 8, pp. 2549-2578, 2016.

[11] A. Rafinda, "Determinants of Cash Holdings in Developed and Developing Countries," J. Din. Manaj., vol. 9, no. 1, pp. 1-11, 2018.

[12] A. Isniawati, R. Rahmawati, and A. Budiatmanto, "Pengaruh asimetri informasi dan analyst coverage terhadap konservatisme akuntansi," J. Akunt. Audit. Indones., vol. 20, no. 2, pp. 99-109, 2016.

[13] A. L. Wijaya, B. Bandi, and S. Hartoko, "PENGARUH KUALITAS AKRUAL DAN LEVERAGE TERHADAP CASH HOLDING PERUSAHAAN,” J. Akunt. dan Keuang. Indones., 2010.

[14] L. I. Prasetya and E. Wuryani, "PENGARUH NET WORKING CAPITAL, DIVIDEND PAYMENT, CASH CONVERSION CYCLE, DAN OPERATING CASH FLOW TERHADAP CASH HOLDING PERUSAHAAN," Jur. Akunt. Fak. Ekon. Univ. Negeri Surabaya, 2017.

[15] A. D. Syafrizaliadhi and E. D. Arfianto, "FAKTOR-FAKTOR YANG MEMPENGARUHI PERILAKU CASH HOLDINGS PADA PERUSAHAAN BESAR DAN PERUSAHAAN KECIL," diponegoro J. Manag., vol. 3, no. 3, pp. 1-14, 2014.

[16] I. Ghozali, "Aplikasi Analisis Multivariete Dengan Program IBM SPSS 23, Edisi 8," in Badan Penerbit Universitas Diponegoro, 2016.

[17] A. M. Cheryta, M. Moeljadi, and N. K. Indrawati, "Leverage, Asymmetric Information, Firm Value, and Cash Holdings in Indonesia," J. Keuang. dan Perbank., vol. 22, no. 1, pp. 83-93, 2018. 